\title{
ОСОБЛИВОСТІ ЗМІН КАРДІОГЕМОДИНАМІКИ У ПАЦІЄНТІВ ІЗ СТАБІЛЬНОЮ СТЕНОКАРДІЄЮ ТА ГІПОФУНКЦІЕЮ ЩИТОПОДІБНОЇ ЗАЛОЗИ
}

\author{
А. В. Волобуєва, І. Б. Киричок, М. Я. Василенко \\ ТОВ «Медікап», м. Одеса \\ ДВНЗ «Тернопільський державний медичний університет \\ імені І. Я. Горбачевського МОЗ Украӥни"
}

\begin{abstract}
У хворих на стенокардію навантаження за умов йододефіциту часто порушуються процеси обміну, вегетативної регуляції та гемодинаміки. Щоб з'ясувати особливості змін діастолічної функції лівого шлуночка у хворих на стабільну стенокардію навантаження у поєднанні з субклінічним гіпотиреозом, обстежено дві групи пацієнтів: 23 - хворі на ішемічну хворобу серця, стабільну стенокардію навантаження II-III функціонального класу та 21 - на стенокардію у поєднанні з субклінічним гіпотиреозом. Визначали основні показники діастолічної функції лівого шлуночка.

Порівняно 3 пацієнтами 3 ізольованою стабільною стенокардією навантаження відповідного функціонального класу в хворих на стабільну стенокардію навантаження у поєднанні з субклінічним гіпотиреозом зафіксовано більш виражені прояви діастолічної дисфункції лівого шлуночка, із частішим виявленням псевдонормального типу.
\end{abstract}

\section{FEATURES OF CARDIOHEMODYNAMIC CHANGES IN PATIENTS WITH STABLE ANGINA AND HYPOFUNCTION OF THYROID GLAND}

\author{
A. V. Volobueva, I. B. Kyrychok, M. Ya. Vasylenko \\ LLC «Medikap», Odesa \\ I. Horbachevsky Ternopil State Medical University
}

\begin{abstract}
In patients with angina iodine deficiency metabolism, hemodynamics and autonomic regulation can often change. To find out the features of left ventricular diastolic function in patients with stable angina in combination with subclinical hypothyroidism 2 groups of patients were observed. Among them: 23 patients with coronary artery disease: stable angina FC II-III and 21 patients with stable angina in combination with subclinical hypothyroidism. In all observed patients main indicators of left ventricular diastolic function were made.

In patients with stable angina pectoris in conjunction with subclinical hypothyroidism, comparing to patients with isolated stable angina of corresponding FC, detected more pronounced violation of left ventricular diastolic dysfunction, which more often was manifested by pseudonormal type.
\end{abstract}

Вступ. Ішемічна хвороба серця (IXC), за результатами Фремінгемського дослідження, $є$ однією з основних причин розвитку та прогресування хронічної серцевої недостатності (XCH) [1, 5]. Пізніше з'ясовано, що основним механізмом виникнення серцевої недостатності за умов збереження систолічної функції $є$ діастолічна дисфункція лівого шлуночка (ДДлШ). Через малосимптомний перебіг діагностувати дДЛШ на ранніх стадіях досить складно [2, 3].

Варто відзначити, що впродовж останніх років науковці приділяють значну увагу вивченню серцевосудинних уражень за умов йододефіциту, поширення і вираження якого постійно зростає. Відомо, що у

() А. В. Волобуєва, І. Б. Киричок, М. Я. Василенко, 2017 таких хворих значно частіше виникають IXC із проявами стенокардії, дисліпідемія та ХСН. Сьогодні роль ендокринної системи, а саме - гормонів щитоподібної залози, в патогенетичних механізмах атеросклерозу та ХСН вивчена недостатньо [6]. Отже, актуальним $\epsilon$ вивчення гемодинамічних змін серцево-судинної системи за наявності гіпофункції щитоподібної залози.

Основна частина. Обстежено 44 хворих на IXC, стенокардію навантаження II-III функціонального класу (ФК). Стенокардію навантаження II ФК діагностовано у 20 пацієнтів (45,5\%), а III ФК - у 24 (54,5\%). Середній вік обстежених становив $(52,4 \pm 1,7)$ року та коливався від 42 до 74 років. До контрольної групи увійшло 20 практично здорових осіб такого ж віку та статі. 
Усіх хворих поділено на дві групи. До першої групи увійшло 23 пацієнти (52,3 \%) хворих на стенокардію навантаження без проявів гіпофункції щитоподібної залози (ЩЗ), до другої - 21 (47,7 \%) із поєднанням стенокардії навантаження та субклінічного гіпотиреозу.
ДДЛШ оцінювали за допомогою Ехо-КГ. У пацієнтів зі стенокардією навантаження та збереженою функцією щз показник фази швидкого діастолічного наповнення Е достовірно знижувався на 21,1\% порівняно з контрольною групою здорових осіб (табл. 1).



\begin{tabular}{|l|c|c|c|c|c|c|}
\hline \multicolumn{1}{|c|}{ Показник } & $\begin{array}{c}\text { Контрольна група } \\
(\mathrm{n}=20)\end{array}$ & $\begin{array}{c}\text { IХС зі збереженою } \\
\text { функцією щ3 } \\
(\mathrm{n}=23)\end{array}$ & $\begin{array}{c}\text { IXС із субклінічним } \\
\text { гіпотиреозом } \\
(\mathrm{n}=21)\end{array}$ & $\mathrm{p}_{1-2}$ & $\mathrm{p}_{1-3}$ & $\mathrm{p}_{2-3}$ \\
\hline $\mathrm{E}, \mathrm{cm} / \mathrm{c}$ & $0,71 \pm 0,02$ & $0,56 \pm 0,02$ & $0,51 \pm 0,03$ & $<0,01$ & $<0,01$ & $>0,05$ \\
\hline $\mathrm{A}, \mathrm{cm} / \mathrm{C}$ & $0,59 \pm 0,01$ & $0,76 \pm 0,03$ & $0,49 \pm 0,01$ & $<0,01$ & $<0,01$ & $<0,01$ \\
\hline $\mathrm{E} / \mathrm{A}$ & $1,21 \pm 0,04$ & $0,74 \pm 0,02$ & $1,08 \pm 0,08$ & $<0,01$ & $>0,05$ & $<0,01$ \\
\hline $\mathrm{E}^{\prime}, \mathrm{CM} / \mathrm{c}$ & $0,13 \pm 0,01$ & $0,06 \pm 0,01$ & $0,05 \pm 0,01$ & $<0,01$ & $<0,01$ & $>0,05$ \\
\hline $\mathrm{E} / \mathrm{E}^{\prime}$ & $5,78 \pm 0,30$ & $9,07 \pm 0,43$ & $11,26 \pm 0,64$ & $<0,01$ & $<0,01$ & $<0,05$ \\
\hline $\mathrm{DT}, \mathrm{MC}$ & $177,00 \pm 2,75$ & $209,70 \pm 0,87$ & $190,86 \pm 1,84$ & $<0,01$ & $<0,01$ & $<0,01$ \\
\hline IVRT, MC & $83,40 \pm 2,53$ & $104,00 \pm 0,92$ & $93,29 \pm 2,03$ & $<0,01$ & $<0,01$ & $<0,01$ \\
\hline
\end{tabular}

Примітки: $\mathrm{p}_{1-2}$ - достовірність відмінності показників у хворих зі збереженою функцією щз порівняно $з$ контрольною групою; $p_{1-3}$ - достовірність відмінності показників у хворих із субклінічним гіпотиреозом порівняно 3 контрольною групою; $p_{2-3}$ - достовірність відмінності показників у хворих із субклінічним гіпотиреозом порівняно зі збереженою функцією щз.

У хворих із поєднанням стенокардії навантаження та субклінічного гіпотиреозу значення Е знижувалось на 28,2 \% (p<0,01) порівняно з контрольною групою та було меншим на 8,9% (p>0,05) порівняно з пацієнтами, у яких збережена функція щз. Аналіз змін показника фази пізнього діастолічного наповнення А показав, що у пацієнтів першої групи цей показник зростав на 28,8 \% порівняно з контрольною групою. Значення піка А у хворих другої групи знижувалося на 16,9 \% порівняно з контрольною групою та на 35,5 \% - порівняно з хворими першої групи. Це пояснюється тим, що з наростанням тяжкості стенокардії навантаження та ії поєднанням із субклінічним гіпотиреозом погіршуються показники ДДЛш. Співвідношення Е/А у хворих зі збереженою функцією щЗ достовірно знижувалось на 38,8 \% порівняно з контрольною групою та на 31,5 \% - із пацієнтами з субклінічним гіпотиреозом. У хворих другої групи дДЛш співвідношення Е/А було нижчим на 10,7 \% порівняно з контрольною групою.

Співвідношення Е/Е' у хворих із релаксаційним типом становить <10 внаслідок зниження як показника $\mathrm{E}$, так і показника Е', протеу хворих із псевдонормальним типом це значення становить $>10$. Із наростанням тяжкості дДлш зростає тиск у лівому передсерді і, як наслідок, відбувається псевдонормалізація потоків: зростає пік E, але Е' знижується, і саме за рахунок цього співвідношення Е/Е' збільшується. У нашому дослі- дженні в обстежених пацієнтів першої групи показник Е' достовірно знижувався на 53,8 \%, у хворих другої групи - на 61,5 \% порівняно з контрольною групою здорових осіб. При поєднанні стабільної стенокардії та субклінічного гіпотиреозу середнє значення E/E' становило $(11,26 \pm 0,64)$ та було значно вище норми $(p<0,01)$, а за умов збереження функції щз середнє значення Е/Е' становило $(9,07 \pm 0,43)$. Отримані результати $\epsilon$ зіставними з опублікованими у світовій літературі [4, 7]. У хворих першої групи час сповільнення піка E (DT) подовжувався на 18,5 \% порівняно з контрольною групою, а у пацієнтів другої групи DT не був подовженим, проте був достовірно вищим на 7,8 \% порівняно з контрольною групою здорових осіб. Значення IVRT у хворих зі збереженою функцією щз, а також у пацієнтів зі стенокардією навантаження та субклінічним гіпотиреозом було достовірно вищим (на 24,7 та 11,9 \% відповідно) порівняно з контрольною групою.

Загалом, серед обстежених пацієнтів у 24 хворих (54,5 \%) виявлено релаксаційний тип ддлш, а у 20 (45,5 \%) - псевдонормальний тип. Аналіз отриманих результатів з урахуванням поділу групи дав змогу діагностувати у пацієнтів першої групи релаксаційний тип дДлш у 18 хворих (78,3 \%), псевдонормальний у 5 (21,7 \%). Серед обстежених другої групи релаксаційний тип діагностовано у 6 хворих (28,6\%), а псевдонормальний - у 15 пацієнтів $(71,4 \%)$. 
Таким чином, вивчення змін стану кардіогемодинаміки у хворих на стенокардію навантаження за умов йододефіциту є досить важливим через те, що перебіг IXC суттєво видозмінюється із переважанням ДДЛШ найчастіше у вигляді псевдонормального типу.

Висновки. 1. У всіх обстежених пацієнтів обох груп виявлено ознаки діастолічної дисфункції лівого шлуночка.

\section{СПИСОК ЛІТЕРАТУРИ}

1. Беловол А. Н. Сердечная недостаточность: диагностика и мониторинг в процессе терапии / А. Н. Беловол, И. И. Князькова // Серцева недостатність. - 2012. № 1. - С. 24-39.

2. Диастолическая дисфункция левого желудочка и ее роль в развитии хронической сердечной недостаточности / С. Н. Терещенко, Н. В. Демидова, Л. Г. Александрия, Ф. Т. Агеев // Сердечная недостаточность. - 2000. № 2. - С. 96-102.

3. Камышникова Л. А. Диастолическая дисфункция при хронической сердечной недостаточности - основные диагностические параметры и критерии тяжести / Л. А. Камышникова, О. А. Ефремова // Медицина. Фармация. - 2009. - № 7. - С. 9-13.
2. У пацієнтів першої групи переважав релаксаційний тип діастолічної дисфункції, який діагностовано у 18 хворих (78,3 \%), а серед обстежених другої групи достовірно частіше діагностували псевдонормальний тип у 15 пацієнтів (71,4\%).

3. У пацієнтів із поєднанням стенокардії навантаження та субклінічного гіпотиреозу порушення ДДлШ є більш вираженими, ніж у пацієнтів з IXC без супутнього субклінічного гіпотиреозу.

4. Райдинг Э. Эхокардиография : практ. руководство / Э. Райдинг. - М. : МЕДпресс-информ, 2010. - 280 с.

5. Хроническая сердечная недостаточность, обусловленная ишемической болезнью сердца / Н. Т. Ватутин, Н. В. Калинкина, А. Н. Шевелек, В. В. Адаричев // Серцева недостатність. - 2010. - № 2. - С. 95-106.

6. Clinical Practice Guidelines for Hypothyroidism in Adults: Cosponsored by the American Association of Clinical Endocrinologists and the American Thyroid Association / Jeffrey R. Garber, Rhoda H. Cobin, Hossein Gharib [et al.]. 2012.

7. Otto C. Textbook of clinical echocardiography. $-5^{\text {rd }}$ ed. / C.Otto. - LSVR SAUNDERS, 2014. - P. 541. 